\title{
BIOCHEMICAL, IMMUNOLOGICAL AND PATHOLOGICAL STUDIES ON BROILER FED AFLATOXIN B1 CONTAMINATED DIET TREATED BIOLOGICALLY BY LACTOBACILLUS ACIDOPHILUS OR SACCHAROMYCES CEREVISIAE
}

\author{
A.E. Abou-Zeid; S.Z. El-Damarawy and T.K. El-Rayes \\ Animal Production Department, Faculty of Agriculture, Tanta University, Egypt.
}

\section{SUMMARY}

\begin{abstract}
trial was carried out to shed more light on the precautionary efficiency of Lactobacillus $\triangle$ acidophilus and Saccharomyces cerevisiae in ameliorating the toxic effects of aflatoxin B1 (AFB1) in broiler chicks. Two hundred and forty one-day-old unsexed Cobb broilers chicks
\end{abstract} were separated randomly into four equal experimental groups; with three replicates of 20 chicks each. The first group was received basal diet without aflatoxin B1 (control negative), while the other three groups were given basal diets containing 300 ppb AFB1. Within each aflatoxin treatment, the first group (control positive) was fed the contaminated diet without any treatment; the second was fed contaminated diet treated with $L$. acidophilus and the third was fed contaminated diet treated with S. cerevisiae. At the end of the experiment, biochemical traits, $\mathrm{HI}$ titer, and histopathological profile of broilers fed contaminated diet (300ppb AFB1/kg) (treated and not treated) were studied. The results showed that serum total protein, albumin, globulin, $\operatorname{IgG}$ and Ig, cholesterol and triglycerides were significantly decreased in the broilers fed diet containing 300 Ppb AFB1 as compared with those fed negative control diet. However, the activity of ALT and AST in blood serum was significantly increased in the broilers fed diet containing 300 Ppb AFB1 as compared with negative control. The same trend was observed in concentration of uric acid and creatinine. Although, all groups had haemaglutination inhibiting antibodies against NDV, the highest haemaglutination inhibiting antibody titer was obtained from birds not exposed to AFB1 at 35 days of age. In addition, data showed that the biological treatment by $L$. acidophilus or S. cerevisiae did not influence the humoral immune response of broiler against NDV. In addition, the histopathological study showed the ability of biological treatment to reduce the negative effects of AFB1 on liver and kidney tissues. It could be recommended that using L. acidophilus and S. cerevisiae supplementation in the feed to ameliorate toxic effects of aflatoxin B1 in broilers.

Keywords: Broilers, Aflatoxin B1, L. acidophilus, S. Cerevisiae and biochemical traits.

\section{INTRODUCTION}

Aflatoxins (AFs) are highly toxic, mutagenic, teratogenic and carcinogenic compounds produced by some species of Aspergillus, especially A. flavus and A. parasiticus under tropical and subtropical climates (Han et al., 2008). Particularly aflatoxin B1 (AFB1), are considered to be the most important of the mycotoxins due to their high toxicity and they are still of major concern to the feed industry (FAO/ WHO, 2001).

Wu et al. (2009) reported that biodegradation of aflatoxins, using microorganisms or enzymes, is one of the well-known strategies. The methods of biodegradation are being actively studied and can be a highly promising choice, since it is efficient, specific, and environmentally friendly to reduce or eliminate the possible contaminations of aflatoxins in foods and feeds.

In Egypt, aflatoxicosis in poultry is more or less frequent, so, this study was conducted to study the effects of feeding aflatoxin B1 on some blood biochemical parameters and immunological traits besides, histopathological profile of liver and kidney of broiler chicks. 


\section{MATERIALS AND METHODS}

The present study was carried out at a private poultry farm under supervision of Animal Production Department, Faculty of Agriculture, Tanta University, during the period from September to November 2014. This study was carried out to investigate the effect of feeding contaminated diets with $300 \mathrm{ppb}$ AFB1/ kg diet treated biologically on some blood biochemical traits besides, HI titer and histopathological profile.

\section{Experimental design:}

Two hundred and forty one-day-old unsexed Cobb broilers chicks were used in this experiment. Birds were wing-banded, individually weighed to the nearest gram, and randomly distributed into four equal experimental groups; with three replicates of 20 chicks each. The average initial body weights of the treatments groups were nearly similar with no observed significant differences. Chicks were grown in floor pens and subjected to $23 \mathrm{hrs}$ lighting along the experimental period which extended to 6 weeks of age. The room temperature was kept at about $34^{\circ} \mathrm{C}$ during the first 3 days, $32^{\circ} \mathrm{C}$ during next 4 days and thereafter, gradually decreased by $2{ }^{\circ} \mathrm{C}$ weekly down to $24^{\circ} \mathrm{C}$. Mash feed form and water were available ad libitum throughout the experimental period. All experimental groups were reared under similar managerial and hygienic conditions.

\section{Experimental diets:}

The basal diet was a commercial corn-soybean meal diet formulated to meet or exceed the nutritional requirement of growing chicks as recommended by NRC (1994) as shown in Table 1.

Dietary treatments included:

1) Basal diet (negative control) without any addition

2) Basal diet supplemented with $300 \mathrm{ppb} / \mathrm{kg} \mathrm{AFB}$ (positive control)

3) Basal diet containing $300 \mathrm{ppb} \mathrm{AFB}_{1}$ treated with Lactobacillus acidophilus

4) Basal diet containing $300 \mathrm{ppb} \mathrm{AFB}_{1}$ treated with saccharomyces cerevisiae.

\section{Measurements:}

\section{Biochemical parameters:}

At 6 weeks of age, nine birds from each group (3 birds from each replicate) were randomly selected, slaughtered and blood samples were collected. Blood serum was separated by centrifugation at $3000 \mathrm{rpm}$ for $20 \mathrm{~min}$. The collected serum was kept frozen at - 20oC until assay for determination of the following biochemical parameters:

Serum total protein, albumin, globulin, IgG and IgM, AST, ALT, triglycerides, total cholesterol, uric acid and serum creatinine.

\section{Haemagglutination Inhibition (HI) test:}

At 35 days of age (after 12 days of Lasota vaccination), blood samples were collected. Blood serum was separated by centrifugation at $3000 \mathrm{rpm}$ for $20 \mathrm{~min}$. The collected serum was kept frozen at - 20oC until assay. The beta-procedure of the HI test was employed as a micro-test in plastic plates as outlined in "Methods for Examining Poultry Biologics and for Identifying and Quantifying Avian Pathology" (Anon, 1990).

\section{Histological Examination:}

For the histological study, tissue specimens were collected from the liver and kidney of all groups. Paraffin blocks were done, and then paraffin sections of 3-5 micron thick were prepared and followed by staining with hematoxylin and eosin (Lillie, 1984) and then subjected for the light microscopy examination.

\section{Statistical analysis:}

Data were statistically analyzed by one-way ANOVA, using the general linear model procedure (SAS, 1996). Tests of significance for differences among treatments were done according to Duncan (1955). The statistical model was used for the analysis of variance to estimate the effect of biological treatment on detoxification of AFB1 as follows:

$Y i j k=U+T i+R j+e i j k$ 
Where, Yijk is the observations; $\mathrm{U}$ is overall mean; Ti is effect of $\mathrm{i}$ the treatment $(\mathrm{i}=1,2,3$ and 4$)$; $\mathrm{Rj}$ is effect of $\mathrm{j}$ the replicate $(\mathrm{j}=1,2$ and 3 ) and eijk is residual (random error)

\section{RESULTS AND DISCUSSION}

\section{Biochemical parameters:}

The blood serum constituents of broilers chicks as affected by 300 Ppb AFB1 contaminated diet, biologically treated by L. acidophilus or S. cerevisiae are presented in Tables (2-A \& 2-B). It is obvious that, there was interspecific variation in all investigated serum parameters between treated groups and negative control. Serum total protein decreased significantly $(\mathrm{P} \leq 0.05)$ in birds received contaminated diet with $300 \mathrm{Ppb}$ AFB1 by $41.46 \%$, compared with the negative control group. However, there were no difference between treated biologically groups and negative control. A similar pattern of response to that described of total protein was noticed with albumin, globulin, IgG and IgM. Where serum albumin, globulin, IgG and IgM in birds received contaminated diet with 300 Ppb AFB1 were statistically differing compared with the negative control. Albumin and globulin concentration decreased by 53.42 and $42.97 \%$, respectively, compared to the negative control.

The highest concentration of immune globulin $\mathrm{G}(\mathrm{IgG})$ and immune globulin $\mathrm{M}$ (IgM) observed in negative control group lining 0.986 and $0.122(\mathrm{~g} / \mathrm{l})$ respectively. While, the lowest value obtained by birds fed $300 \mathrm{Ppb}$ AFB1 contaminated diet. Moreover, there was an improvement in the concentration of IgG and IgM in the birds fed contaminated diet treated with L. acidophilus or S. cerevisiae. In addition, data of $\mathrm{A} / \mathrm{G}$ ratio showed no significant differences between all groups.

These results are in harmony with Hashem and Mohamed (2009) who found that a reduction in serum total protein, albumin and globulin when fed broiler chicks contaminated diet with $4 \mathrm{mg} \mathrm{AF} / \mathrm{kg}$ of diet for 21 days of age. The reduction of the serum total protein, associated with hypoalbuminaemia and hypoglobulinaemia, may be due to the interaction of AFB1 with DNA, RNA and intercellular proteins of chicken-hepatocytes, leading to impaired protein synthesis and leakage of albumin due to nephrotoxicity induced by AFs. (Abdel-Rahman et al., 2002; Quezada et al., 2002 and Raju and Devegowda, 2000).

Opposite trend was detected with the activity of AST and ALT. The activity of AST and ALT in blood serum was increased significantly $(\mathrm{P} \leq 0.05)$ in birds fed 300 Ppb AFB1 contaminated diet compared to negative control group.

These results are compatible with Hashem and Mohamed (2009) who found that a significant increasing in the activity of ALT and AST of broiler chicks fed contaminated diet with $4 \mathrm{mg} \mathrm{AF} / \mathrm{kg}$ of diet for 21 days of age. In addition, Hathout et al. (2011) cited that, rats fed on AF contaminated diet (3 $\mathrm{mg} / \mathrm{kg}$ diet) increased the activity of ALT and AST in serum. While, rats fed contaminated diet treated with lactic acid bacteria decreased significantly in the activity of AST and ALT compared with those fed contaminated diet. Also, Abdel-Wahhab et al. (2008) reported that the increased level of ALT and AST might indicate degenerative changes and hypo-function of liver.

In consistent, Cheng et al. (2001), Bintvihok and Davitiyananda (2002) and Han et al. (2008) reported ducks fed contaminated diets had greater activities of ALT and AST in serum, indicating that the liver functions was damaged. The ALT and AST, mainly existed in liver, were two important enzymes for the conversion between carbohydrate and protein. When liver cells were damaged or cell membrane permeability increased, ALT and AST permeated into blood and, consequently, these enzyme activities increased, whose increasing levels went along with the lesion degree of liver cells.

The results in Table (2-B) indicated that serum uric acid was significantly increased by $60 \%$ in groups fed $300 \mathrm{Ppb}$ AFB1 contaminated diet compared to the negative control group. Serum creatinine concentration takes the same trend of response to that described of serum uric acid. Serum creatinine concentration of birds fed contaminated diet with 300 Ppb AFB1 increased significantly $(\mathrm{P} \leq 0.05)$ by $66.66 \%$ compared to the negative control. On the other hand, there were no significantly differences between broilers fed biologically treated groups and negative control in serum creatinine concentration.

These results are in agreement with Hashem and Mohamed (2009) who reported that a significant increasing in the concentration of uric acid and creatinine when fed broiler chicks contaminated diet with $4 \mathrm{mg} \mathrm{AF} / \mathrm{kg}$ diet from 1 to 21 days of age. The high concentration of uric acid and creatinine may indicate protein catabolism and/ or kidney dysfunction (Abdel-Wahhab et al., 2007).

Serum triglycerides concentration of chicks fed contaminated AFB1 diet was significantly $(\mathrm{P} \leq 0.05)$ decreased compared with the negative control diet. However, there were no significant differences between broilers fed treated biologically contaminated feeds and negative control group. A similar pattern of response to that described for serum triglycerides was noticed for serum cholesterol concentration; it decreased in broilers fed $300 \mathrm{Ppb}$ AFB1 contaminated diet as compared with the negative control group. 
Serum cholesterol in birds received treated biologically contaminated feeds was not statistically differing than of the negative control.

These results are compatible with Abd El-Hamid et al. (1992) who reported that serum triglycerides and cholesterol were reduced by aflatoxicosis when broiler chicks were fed on dietary aflatoxin (4 ppm) from 1 to 21 days of age. The serum TC and TG were reduced by contaminated diets, which agreed with Huff et al. (1986) who reported similar findings in broilers fed AFB1 diets. The liver damaged by AFB1 contaminated diets could decrease TC synthesis. The TG is fatty acid esters of glycerol and come from food, as well as being produced by the body. They are secreted from the liver into the blood by TG-rich lipoproteins and, therefore, decreased TG concentration may be due to impaired hepatic lipogenesis. The elevation of TC and TG are probably associated with biliary obstruction and acute hepatic injury (Edrington et al., 1997). These results clearly indicated that AFs had stressful effects on the hepatic and renal tissues, consistent with those reported in the literature of aflatoxicosis (Miller and Willson, 1994; Abdel-Wahhab and Kholif, 2008; Sherif et al., 2009).

In the current study, treatment with L. acidophilus or S. cerevisiae succeeded to prevent the liver and kidney injury resulted from AFB1 as indicated by the significant improvement in serum biochemical parameters and histological picture of the liver. The mechanism by which L. acidophilus or S. cerevisiae induce their preventive facts may be due to their ability to bind AFB1 in the gastrotestinal tract and consequently reduce the bioavailability of AFB1.

\section{Immune response to Newcastle disease (ND) vaccine:}

Geometric means of titers (GMT) of haemagglutination inhibiting antibodies (HI) from serum at 35 days of age (expressed as logarithm on base 2) in the different treatments are presented in Table (3).

Although, all groups had haemagglutination inhibiting antibodies against NDV, the highest haemagglutination inhibiting antibody titer was obtained from birds not exposed to AFB1 at 35 days of age, indicating that the aflatoxin impact negatively on the humoral immune response of broiler vaccinated against NDV as was observed by (Santin et al., 2003). In addition, data showed that the biological treatment by L. acidophilus or S. cerevisiae did not influence significant the humoral immune response of broiler against NDV.

These results are compatible with those observed by Gabal and Azzam (1998) and Santin et al., (2003) who reported that, the humoral immune response of broilers vaccinated against NDV was reduced for aflatoxin in diet. Moreover, the addition of S. cerevisiae to contaminated diet did show insignificant improvement in haemagglutination inhibiting antibodies titers. The immune suppression in broilers exposed to aflatoxin was described by Qureshi et al. (1998), that suggesting the aflatoxin interference with protein metabolism as the case of this damage.

\section{Histological examination:}

\section{Histology of liver:}

Regarding to the histological study, the microscopic examination for the liver of the negative control group revealed normal histological structure of the hepatic tissues and hepatocytes, with no histological alterations (Fig.1). The liver sections of birds fed on aflatoxicated diets (300 ppb) showed that, several markedly congested blood vessels with inflammation, congested central vein and portal tract with inflammatory reaction (Figs. 2, 3 and 4).

The high power magnification showed severe dilatation of portal veins as well as infiltrated hepatocytes, proliferated bile duct, heavily inflammatory hepatocytes with fatty changes (small amounts of lipid droplets can be seen in the cytoplasm of hepatocytes) and small to large focal areas of necrosis were showed (Figs. 5,6,7 \& 8). These histological changes in the liver could explain the results of increasing of liver enzymes (ALT\&AST) in the broilers chickens received diet containing high level of jojoba meal.

The liver sections in birds fed on aflatoxicated diets (300 ppb) treated biologically with L. acidophilus observed minimum improvement in hepatocytes architecture, but there were mild congested blood vessels associated with mild inflammation, moderate dilated blood vessel and moderate congested portal tract (Figs.9, 10 \&11). The high power magnification showed that, proliferated bile duct and mild fatty changes in hepatocytes (Fig. 12). The liver sections in birds fed on aflatoxicated diets (300 ppb) treated biologically with S. cerevisiae showed no histological changes except mild congested blood vessels and mild congested portal tract (Figs.13\&14).

\section{Histology of kidney:}


The microscopic examination for the kidneys of the negative control group revealed normal histological structure for the renal tubules and glomeruli (Fig. 15). The kidney sections of birds fed on aflatoxicated diets $(300 \mathrm{ppb})$ showed several markedly congested blood vessels, dilated vessels with inflammation reaction and atrophy glomeruli, (Figs. 16, 17 \&18). The high power magnification showed that, hydropic degeneration of epithelial cells lining renal tubules and thickened Bowman's capsule basement membrane of the glomerular capillaries (Figs. 19\&20). These changes are considered the main reason for the increase level of creatinine and uric acid in serum of broilers chicks received a contaminated diet containing $300 \mathrm{ppb}$ of AFB1.

The kidney sections in birds fed on aflatoxicated diets $(300 \mathrm{ppb})$ treated biologically with $\mathrm{L}$. acidophilus showed congested blood vessels associated with mild inflammation, in normal glomeruli and dilated renal blood vessels (Figs.21 \&22). The kidney sections in birds fed on aflatoxicated diets $(300$ $\mathrm{ppb}$ ) treated biologically with S. cerevisiae showed no histological changes except mild congested blood vessels with mild inflammation (Figs.23 \&24).

The results of histopathology obtained indicate the toxicity of AFB1 on liver and kidney. These results walk in the line with numerous animal studies, which have shown that the liver is the main target organ and therefore the main symptoms of AFB1 exposure in broilers are hepatic injuries.

Del Bianchi et al. (2005) reported that, the liver of AFB1-treated birds had focal areas of necrosis and inflammatory infiltrates, hepatic vacuolar degeneration, bile duct hyperplasia with fibrosis when fed on contaminated diet with AFB1 from 21 to 42 days of age. In addition, Ortatatli et al. (2005) showed a significant $(\mathrm{P}<0.05)$ changes such as slight to moderate hydropic degeneration and/ or fatty changes, bile duct hyperplasia and periportal fibrosis were recorded when fed broiler chicks contaminated diet with AFB1 until 42 days of age. Tessari et al. (2006) evaluated the toxic effect of aflatoxin B1 (AFB1) on broilers from 8 to 41 days of age. Histological changes were observed in liver that include vacuolar degeneration and cell proliferation of bile ducts in the liver and hydropic degeneration in renal tubules in the kidneys.

\section{CONCLUSIONS}

The current study revealed that chicks fed 300 Ppb AFB1 contaminated diet caused many drastic effects in all tested parameter typical to those reported in the literature. And it's very dangerous due to their high toxicity from the view point of poultry production and public health. Biological treatment by using Lactobacillus acidophilus and Saccharomyces cerevisiae succeeded to prevent the toxic effects of AFB1 in broiler. Moreover, there are needs for a lot of scientific efforts in this trend to improve the ability of probiotics strain to ameliorate toxic effects of aflatoxin B1 in broilers.

\section{REFERENCES}

Abd El-Hamid, H.S.; N.S. Isshak; A. El-Swak and A.A. Mandour (1992). Effect of feeding low levels of aflatoxin on productive performance, serum constituents and pathological changes in laying Japanese Quail. Egypt. Poult. Sci., 12:347.

Abdel-Wahab, M.; N. El-Ghawalby; M. Mostafa; A. Sultan; M. El-Sadany; O. Fathy; T. Salah; F. Ezzat (2007). Epidemiology of hepatocellular carcinoma in lower Egypt, Mansoura Gastroenterology Center. Hepatogastroenterology, 54(73):157-62.

Abdel-Wahab, M. and A.M. Kholif, (2008). Mycotoxins in animal feeds and prevention strategies: A review. Asian J. Anim. Sci., 2:7-25.

Abdel-Wahab, M.; M. Mostafa; M. Sabry; M. El-Farrash and T. Yousef (2008). Aflatoxins as a risk factor for hepatocellular carcinoma in Egypt, Mansoura Gastroenterology Center study. Hepatogastroenterology, 55(86-87):1754-9.

Abdel-Rahman, A.; A.K. Shetty and M.B. Abou-Donia (2002). Disruption of the blood brain barrier and neuronal cell death in cingulated cortex, dentate gyrus, thalamus and hypothalamus in a rat model of Gulf-War syndrome. Neurobiol Dis., 10:306-326.

Anon, (1990). Laboratory manual for the isolation and identification of avian pathogens. 3rd Ed., A.A.A.P. Arnold corporation Ithace, New York.

Bintvihok, A. and D. Davitiyananda (2002). Aflatoxins and their metabolites residues in chicken tissues from 5 parts (10 provinces) of Thailand. Thai Journal of Health Research, 16(1):37-50.

Cheng, Y.H.; T.F. Shen; V.F. Pang and B.J. Chen (2001). Effects of aflatoxin and carotenoids on growth performance and immune response in mule duckling. Comp. Biochem. Physiol. Part C., 128:19-26 


\section{Abou-Zeid et al.}

Del Bianchi, M.; C.A. Oliveira; R. Albuquerque; J.L. Guerra and B. Correa (2005). Effects of prolonged oral administration of aflatoxin B1 and fumonisin B1 in broiler chickens. Poult Sci., 84(12):18351840.

Duncan, B.D. (1955). Multiple Range and Multiple F. Test. Biometrics, 11:1- 42.

Edrington, T.S.; L.F. Kubena; R.B. Harvey and G.E. Rottinghous (1997). Influence of a superactivated charcoal on the toxic effects of aflatoxin or T-2 toxin in growing broilers. Poult. Sci., 76:1205-1211.

FAO/ WHO, (2001).Safety evaluation of certain mycotoxins in food.Joint FAO/ WHO Expert committee on food additives, 56th meeting Geneva.

Gabal, M.A. and A.H. Azzam (1998). Interaction of aflatoxin in the feed and immunization against selected infectious diseases in poultry. Effect on one-day old layer chicks simultaneously vaccinated against Newcastle disease, infectious bronchitis and Infectious bursal disease. Avian Pathology, 27:290.

Hathout, A.S.; S.R. Mohamed; A.A. El-Nekeety; N.S. Hassan; S.E. Aly and M.A. Abdel-Wahhab (2011). Ability of Lactobacillus casei and Lactobacillus reuteri to protect against oxidative stress in rats fed aflatoxins-contaminated diet. Toxicon., 58:179-186.

Huff, W.E.; L.F. Kubena; R.B. Harvey; D.E. Corrier and H.H. Mollenhauer (1986). Progression of aflatoxicosis in broiler chickens. Poultry Science, 65:1891-1899.

Han, X.Y.; Q.C. Huang; W.F. Li and Z.R. Xu (2008). Changes in growth performance, digestive enzyme activities and nutrient digestibility of cherry valley ducks in response to aflatoxin B1 levels. Livest. Sci., 119:216-220.

Hashem, MA. and M.H. Mohamed (2009). Haemato- biochemical and pathological studies on aflatoxicosis and treatment of broiler chicks in Egypt. Vet. Ital., 45:323-337.

Lillie, M. (1984). Histopathological Technique. 3rd Ed., lincoinshire, England.

Miller, D.M. and D.M. Wilson (1994). Veterinary Diseases Related to Aflatoxins. The Toxicology of Aflatoxins: Human Health, Veterinary, and Agricultural Significance. D. L. Eaton and J. D. Groopman. San Diego, CA, Academic Press, Inc.:347-364.

NRC (1994). Nutrient requirement of poultry. 9th ed. Nat. Acad. Press, Washington. DC. USA.

Ortatatli, M.; H. Oguz; F. Hatipoglu and M. Karaman (2005). Evaluation of pathological changes in broilers during chronic aflatoxin (50 and $100 \mathrm{ppb})$ and clinoptilolite exposure. Res. Vet. Sci., 78(1):61-68.

Quezada, T.; H. Cuellar; A.G. Valdivia and J.J. Reys (2002). Effects of aflatoxin B1 on the liver and kidney of broilers chickens during development. Comparative Biochemistry and Physiology - Part C: Toxicology, Pharmacology, 125:265-272.

Qureshi, M.A.; J. Brake; P.B. Hamilton; W.M. Hagler and S. Nesheim (1998). Dietary exposure of broiler breeders to aflatoxin results in immune dysfunction in progeny chicks. Poult. Sci., 77:812-819.

Raju, M. and G. Devegowda (2000). Influence of esterified-glucomannan on performance and organ morphology, serum biochemistry and haematology in broilers exposed to individual and combined mycotoxicisis. British Poultry Science, 41(5):640-650.

Santin, E.; A.C. Paulilo; A. Maiorka; L.S.O. Na-kaghi; M. Macan; A.V.F. Silva and C.A. Alessi (2003). Evaluation of the efficiency of Saccharomyces cerevisiaecell wall to ameliorate the toxic effects of aflatoxin in broilers. Inter. J. Poult. Sci., 2:241-344.

SAS (1996). SAS/ STAT User's Guide; Statistics, Ver. 6.04, Fourth edition, SAS Institute, Inc., Carry, NC.

Sherif, S.O.; E.E. Salama and M.A. Abdel-Wahhab,(2009). Mycotoxins and child health: the need for health risk assessment. (Review) Int. J. Hyg. Environ. Health, 212:347-368.

Tessari, E.N.; C.A. Oliveira; A.L. Cardoso; D.R. Ledoux and G.E. Rottinghaus (2006). Effects of aflatoxin B1 and fumonisin B1 on body weight, antibody titres and histology of broiler chicks. $\mathrm{Br}$ Poult Sci., 47(3):357-364.

Wu, Q.; A. Jezkova; Z. Yuan; L. Pavlikova; V. Dohnal and K. Kuca (2009). Biological degradation of aflatoxins. Drug Metabolism, 41(1):1-7. 
Table (1). Composition and calculated analysis of experimental diets.

\begin{tabular}{llll}
\hline Ingredients & \multicolumn{3}{c}{ Experimental diets } \\
\cline { 2 - 4 } & Starter & Grower & Finisher \\
\hline Yellow corn & 50.48 & 58.02 & 63.61 \\
Soybean meal (44\%) & 32.55 & 30.80 & 26.96 \\
Corn gluten meal (62\%) & 7.10 & 2.52 & 1.23 \\
Soybean oil & 6.00 & 4.88 & 4.88 \\
Limestone & 1.45 & 1.30 & 1.20 \\
Dicalcium phosphate & 1.69 & 1.16 & 1.42 \\
Salt & 0.30 & 0.30 & 0.30 \\
Premix** & 0.30 & 0.30 & 0.30 \\
Dl-Methionine & 0.10 & 0.10 & 0.10 \\
L. Lysine & 0.03 & - & - \\
Total & 100.00 & 100.00 & 100.00 \\
Calculated analysis & & & \\
Crude protein (\%) & 23.01 & 20.05 & 18.03 \\
ME (Kcal/ Kg) & 3050 & 3150 & 3200 \\
Ether extract (\%) & 2.40 & 2.50 & 2.66 \\
Crude fiber (\%) & 3.50 & 3.50 & 3.30 \\
Calcium (\%) & 1.03 & 0.90 & 0.86 \\
Available phosphorus (\%) & 0.45 & 0.35 & 0.39 \\
Methionine (\%) & 0.5 & 0.43 & 0.399 \\
Lysine (\%) & 1.11 & 1.00 & 0.90 \\
Price per ton (LE) & 4450 & 4200 & 4050 \\
** Each 3 kg of premix contained: Vit. A 12000IU, Vit. D 2200IU, Vit. E 10mg, Vit. K3 2000mg, Vit. B1 1000mg, Vit. \\
B2 3000mg, Vit. B6 1300mg, Vit. B12 10mg, Pantothenic acid 10mg, Niacin 30mg, Folic acid 1000mg, Biotin 50mg, \\
Choline chloride 300mg, Manganese 60mg, Zinc 50mg, Copper 10mg, Iron 30mg, Iodine 1000mg, Selenium 100mg, \\
Cobalt 100mg and CaCo3 to 3 Kg. & & & \\
& &
\end{tabular}

Table (2-A): Effect of biological treatments on some blood serum constituents (Mean $\pm \mathrm{SE})$ of broiler fed contaminated diet with 300 Ppb AFB 1 at 6 weeks of age.

\begin{tabular}{|c|c|c|c|c|c|c|c|c|}
\hline Treatments & $\begin{array}{l}\text { Parameters } \\
\text { Total } \\
\text { protein } \\
\text { g/ dl }\end{array}$ & $\begin{array}{l}\text { Albumin } \\
\mathrm{g} / \mathrm{dl}\end{array}$ & $\begin{array}{l}\text { Globulin } \\
\text { g/ dl }\end{array}$ & $\begin{array}{l}\mathrm{IgG} \\
\mathrm{g} / 1\end{array}$ & $\begin{array}{l}\operatorname{IgM} \\
\mathrm{g} / 1\end{array}$ & $\begin{array}{l}\mathrm{A} / \mathrm{G} \\
\text { ratio }\end{array}$ & $\begin{array}{c}\text { AST } \\
\mathrm{u} / 1\end{array}$ & $\begin{array}{c}\text { ALT } \\
\mathrm{u} / 1\end{array}$ \\
\hline Negative & 4.92 & 1.61 & 3.70 & 0.986 & 0.122 & 0.92 & 110.50 & 3.27 \\
\hline $\begin{array}{l}\text { control } \\
\text { (NC) }\end{array}$ & $\pm 0.04^{\mathrm{a}}$ & $\pm 0.01^{\mathrm{a}}$ & $\pm 0.03^{\mathrm{a}}$ & $\pm 0.01^{\mathrm{a}}$ & $\pm 0.01^{\mathrm{a}}$ & \pm 0.02 & $\pm 1.12^{\mathrm{c}}$ & $\pm 0.01^{b}$ \\
\hline Positive & 2.88 & 0.75 & 2.11 & 0.948 & 0.115 & 0.43 & 198.33 & 10.23 \\
\hline control (PC) & $\pm 0.01^{\mathrm{b}}$ & $\pm 0.01^{\mathrm{b}}$ & $\pm 0.01^{\mathrm{b}}$ & $\pm 0.01^{\mathrm{b}}$ & $\pm 0.01^{\mathrm{b}}$ & \pm 0.01 & $\pm 5.29^{\mathrm{a}}$ & $\pm 0.22^{\mathrm{a}}$ \\
\hline$(\mathrm{PC}+L$ & 3.73 & 1.11 & 2.13 & 0.977 & 0.120 & 0.45 & 163.33 & 5.41 \\
\hline Acidophilus) & $\pm 0.02^{\mathrm{ab}}$ & $\pm 0.02^{\mathrm{ab}}$ & $\pm 0.01^{\mathrm{b}}$ & $\pm 0.01^{\mathrm{a}}$ & $\pm 0.01^{\mathrm{a}}$ & \pm 0.02 & $\pm 2.12^{\mathrm{b}}$ & $\pm 0.02^{b}$ \\
\hline$(\mathrm{PC}+S$ & 4.03 & 1.21 & 2.92 & 0.980 & 0.122 & 0.52 & 150.50 & 3.87 \\
\hline cerevisiae) & $\pm 0.02^{\mathrm{ab}}$ & $\pm 0.01^{\mathrm{ab}}$ & $\pm 0.02^{\mathrm{ab}}$ & $\pm 0.01^{\mathrm{a}}$ & $\pm 0.01^{\mathrm{a}}$ & \pm 0.01 & $\pm 1.14^{\mathrm{b}}$ & $\pm 0.01^{b}$ \\
\hline Sig. & $*$ & * & $*$ & $*$ & $*$ & NS & $*$ & $*$ \\
\hline
\end{tabular}

-Means of each column followed by the same letter are not significantly different at the 5\% level according to Duncan's Multiple Range Test.

$-N S$ indicate not significant $-*$ indicate $P<0.05$-Negative control $=$ Basel diet - Positive control $=$ Basel diet contains $300 \mathrm{Ppb} \mathrm{AFB}_{1} / \mathrm{Kg}$ diet. 
Table (2-B). Effect of biological treatments on some blood serum constituents (Mean $\pm \mathrm{SE}$ ) of broiler fed contaminated diet with 300 Ppb AFB 1 at 6 weeks of age.

\begin{tabular}{|c|c|c|c|c|}
\hline \multirow[b]{2}{*}{ Treatments } & \multicolumn{4}{|l|}{ Parameters } \\
\hline & $\begin{array}{l}\text { Uric acid } \\
\mathrm{mg} / \mathrm{dl}\end{array}$ & $\begin{array}{l}\text { Creatinine } \\
\mathrm{mg} / \mathrm{dl}\end{array}$ & $\begin{array}{c}\text { Cholesterol } \\
\mathrm{mg} / \mathrm{dl}\end{array}$ & $\begin{array}{c}\text { Triglyceride } \\
\text { mg/ dl }\end{array}$ \\
\hline Negative control (NC) & $6.28 \pm 0.21^{\mathrm{b}}$ & $0.15 \pm 0.01^{\mathrm{b}}$ & $77.33 \pm 0.06^{\mathrm{a}}$ & $143.50 \pm 1.12^{\mathrm{a}}$ \\
\hline Positive control (PC) & $10.05 \pm 0.14^{\mathrm{a}}$ & $0.25 \pm 0.01^{\mathrm{a}}$ & $61.00 \pm 0.02^{\mathrm{b}}$ & $62.17 \pm 0.21^{\mathrm{b}}$ \\
\hline$(\mathrm{PC}+$ L. Acidophilus $)$ & $9.93 \pm 0.03^{\mathrm{a}}$ & $0.21 \pm 0.02^{\mathrm{ab}}$ & $71.17 \pm 0.02^{\mathrm{a}}$ & $70.83 \pm 0.32^{\mathrm{b}}$ \\
\hline$(\mathrm{PC}+S$. cerevisiae $)$ & $8.97 \pm 0.10^{\mathrm{a}}$ & $0.16 \pm 0.01^{\mathrm{b}}$ & $71.67 \pm 0.01^{\mathrm{a}}$ & $92.83 \pm 1.01^{\mathrm{ab}}$ \\
\hline Sig. & $*$ & $*$ & $*$ & $*$ \\
\hline
\end{tabular}

Table (3). Effect of biological treatments on HI titer of broiler fed contaminated diet with $300 \mathrm{Ppb}$ AFB1.

\begin{tabular}{lcccccc}
\hline Treatment & $\begin{array}{l}\text { Negative } \\
\text { Control }\end{array}$ & Positive control & $\begin{array}{l}(\mathrm{PC}+ \\
\text { Acidophilus })\end{array}$ & L. & $(\mathrm{PC}+$ S. cerevisiae $)$ & Sig. \\
\hline HI Titer & $6.00 \pm 0.85$ & $3.83 \pm 0.87$ & $4.5 \pm 0.81$ & $4.5 \pm 0.91$ & $\mathrm{NS}$ \\
\hline
\end{tabular}

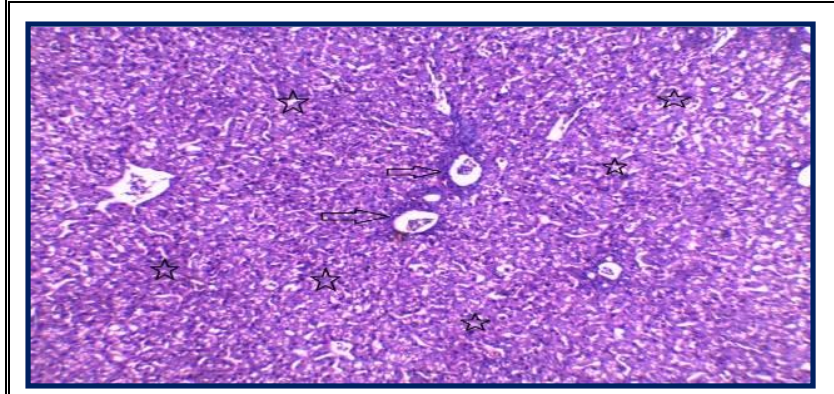

Fig. (1). Liver of negative control birds showing normal hepatocytes (arrows), normal blood vessels (asterisks). . H and E. $\times 200$.

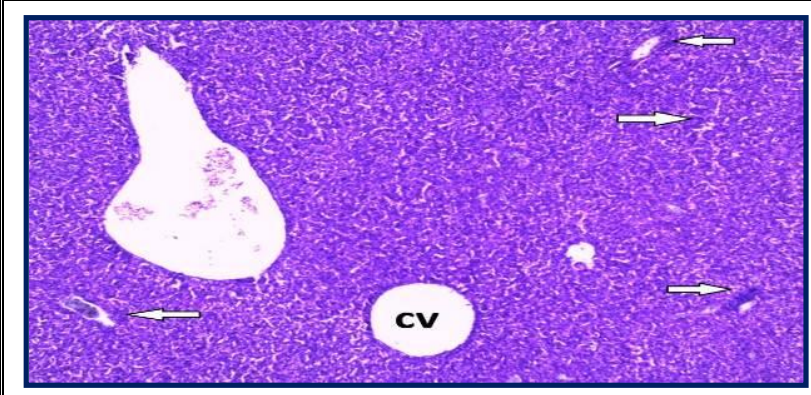

Fig. (3): Liver of aflatoxicated birds showing congested central vein (cv) and portal vessels inflammatory reaction hepatocytes (arrows). $\mathrm{H}$ and $\mathrm{E} . \times 100$.

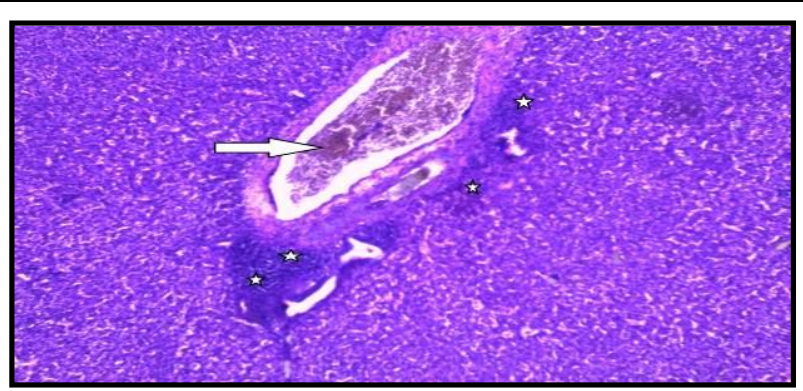

Fig. (2). Liver of aflatoxicated birds showing congested blood vessels (arrow) associated with inflammatory reaction hepatocytes (asterisks). $\mathrm{H}$ and E. $\times 100$.

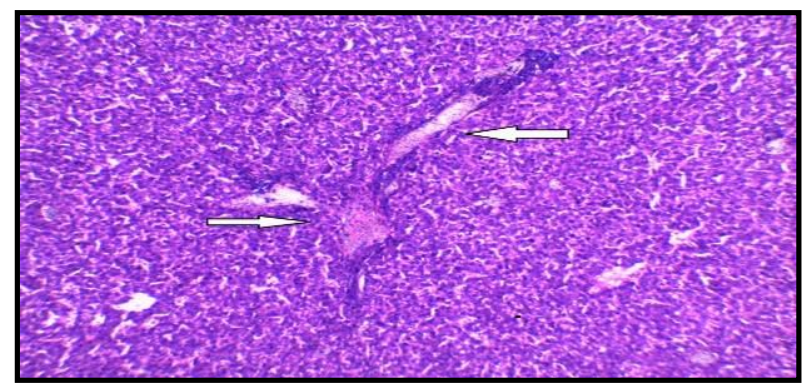

Fig. (4). Liver of aflatoxicated birds showing two portal vessels with heavily inflammatory reaction (arrows). $\mathrm{H}$ and E. $\times 200$. 


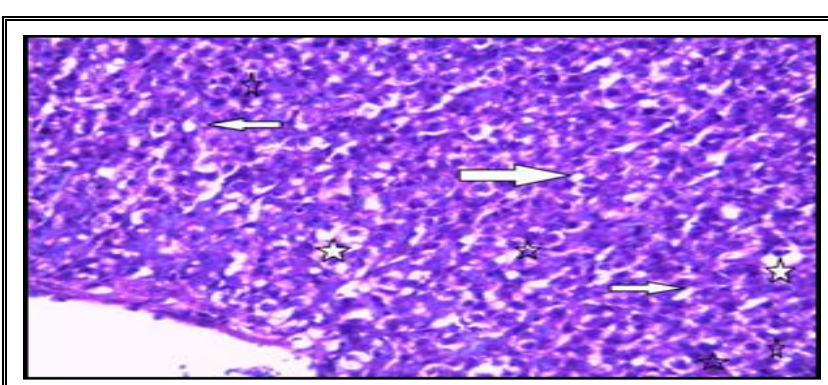

Fig. (5). High power magnification for the liver of aflatoxicated birds showing hepatocytes infiltration (white asterisks), hepatocytes fatty changes (arrows) and hepatocytes dilated (black asterisks). H and E. $\times 400$

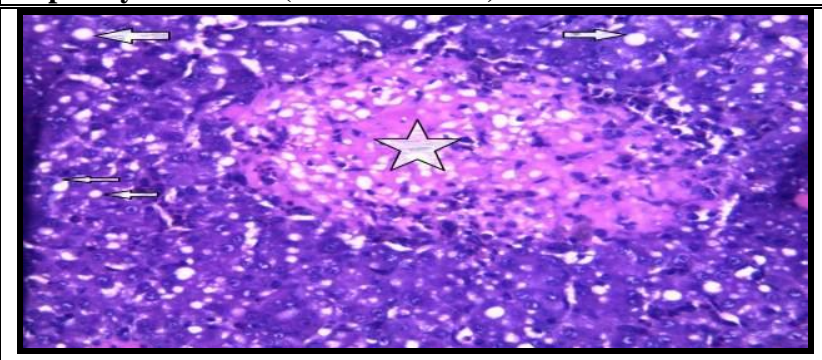

Fig. (7). High power magnification for the liver of aflatoxicated birds showing focal area of necrosis (asterisk) and hepatocytes fatty changes (arrows). $\mathrm{H}$ and $\mathrm{E} . \times \mathbf{4 0 0}$.

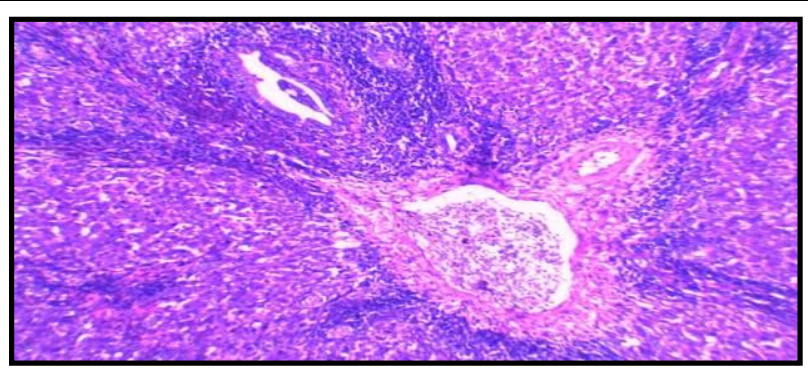

Fig. (6). High power magnification for the liver of aflatoxicated birds showing proliferated bile duct and highly dilated portal tract. $\mathrm{H}$ and $\mathrm{E} . \times \mathbf{4 0 0}$.

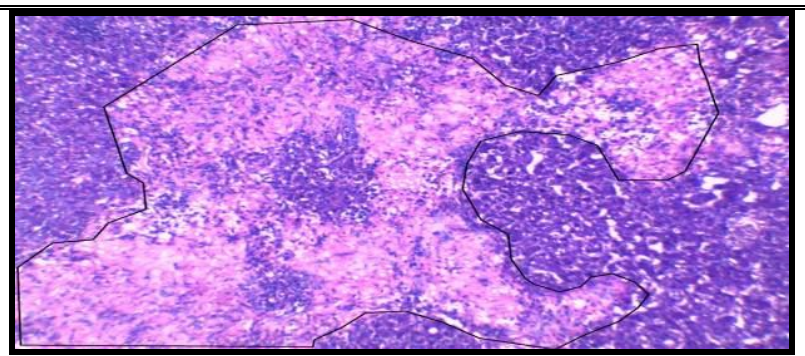

Fig. (8). Liver of aflatoxicated birds showing large area of necrosis. $H$ and $E . \times 200$. 


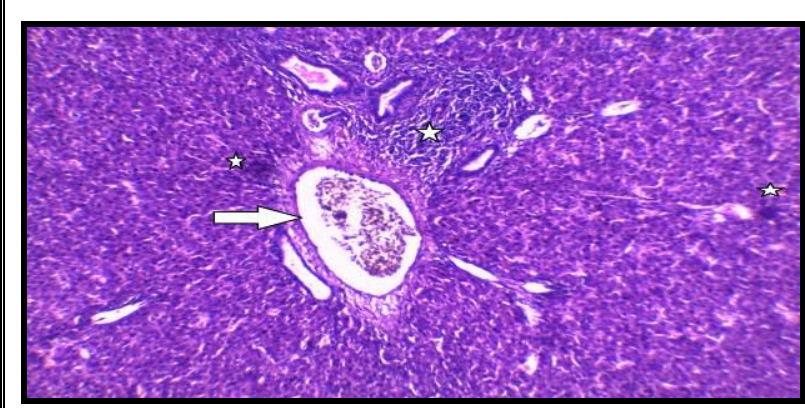

Fig. (9). Liver of aflatoxicated birds treated by $L$. acidophilus showing moderate dilated blood vessel (arrow), inflammatory hepatocytes reaction (asterisks). . $\mathrm{H}$ and $\mathbf{E}$. $\times 200$.

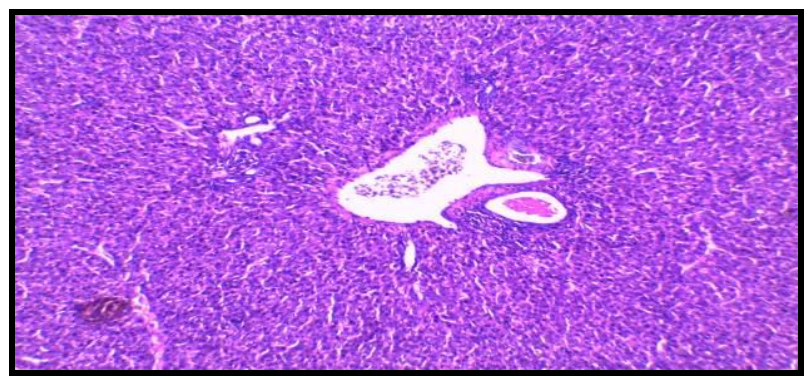

Fig. (11). Liver of aflatoxicated birds treated by $L$. acidophilus showing mild congested blood vessels. $H$ and $\mathbf{E}$. $\times 200$.

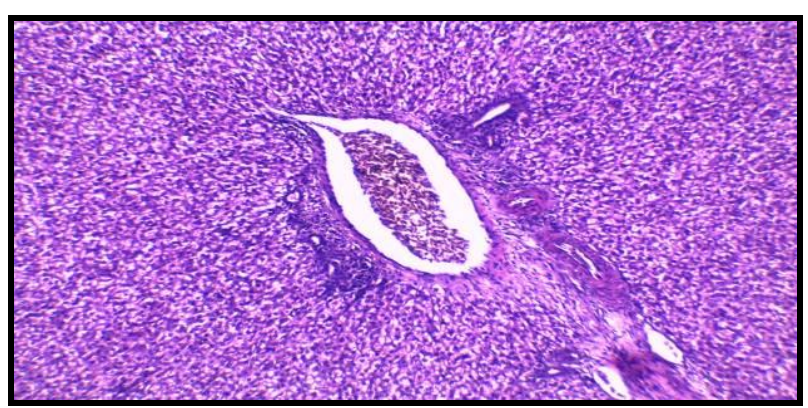

Fig. (13). Liver of aflatoxicated birds treated by $s$. cerevisiae showing moderate congested blood vessel with inflammatory hepatocytes reaction. $\mathrm{H}$ and $\mathrm{E} . \times 200$.

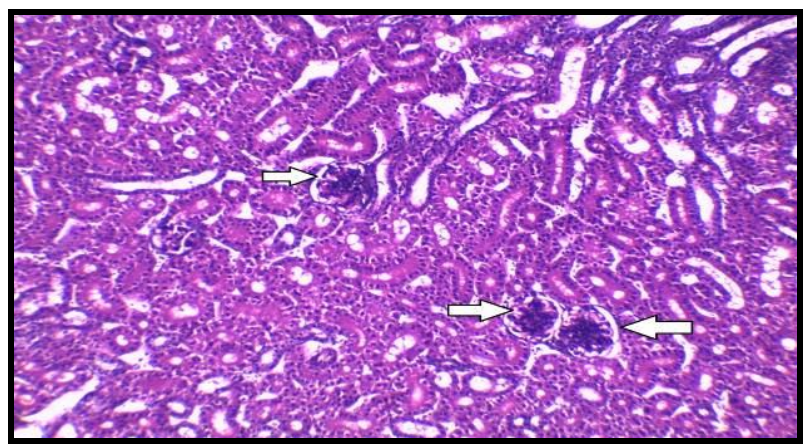

Fig. (15). kidney of negative control birds showing normal renal tissues with normal glomeruli (arrows). $\mathbf{H}$ and $\mathbf{E}$. $\times 200$.

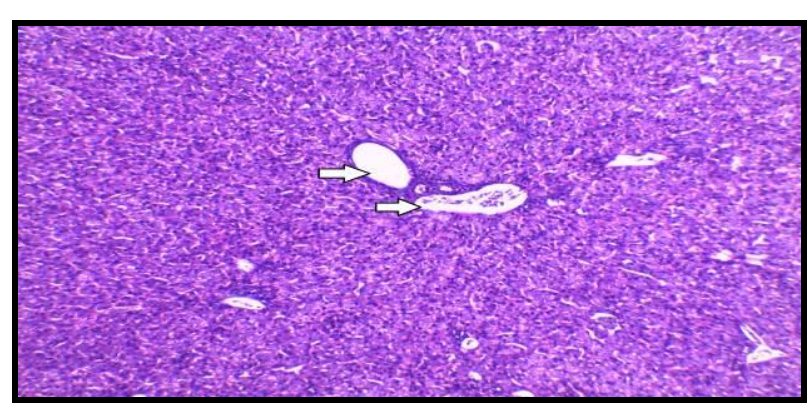

Fig. (10). Liver of aflatoxicated birds treated by $L$. acidophilus showing mild congested portal tract (arrows). H and E. $\times 200$.

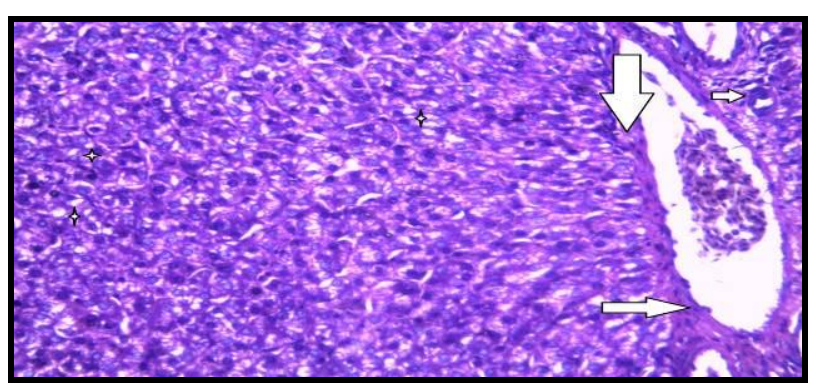

Fig. (12). Liver of aflatoxicated birds treated by $L$. acidophilus showing proliferation in bile duct (arrows), hepatocytes fatty changes (asterisks). . H and E. $\times 400$.

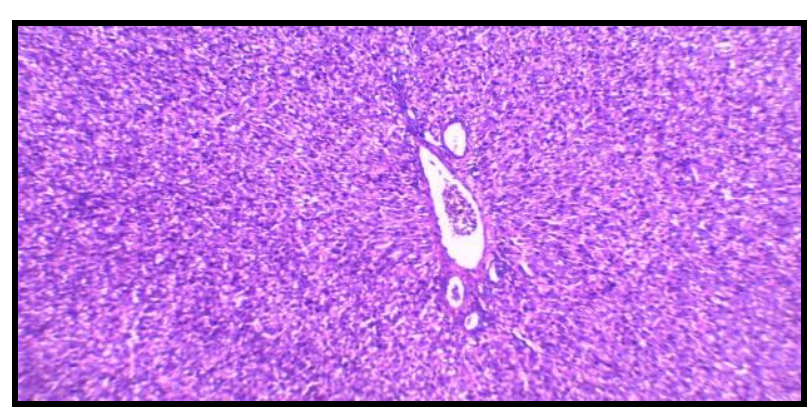

Fig. (14). Liver of aflatoxicated birds treated by s. cerevisiae showing mild congested portal tract with normal hepatocytes. $\mathrm{H}$ and E. $\times \mathbf{2 0 0}$.

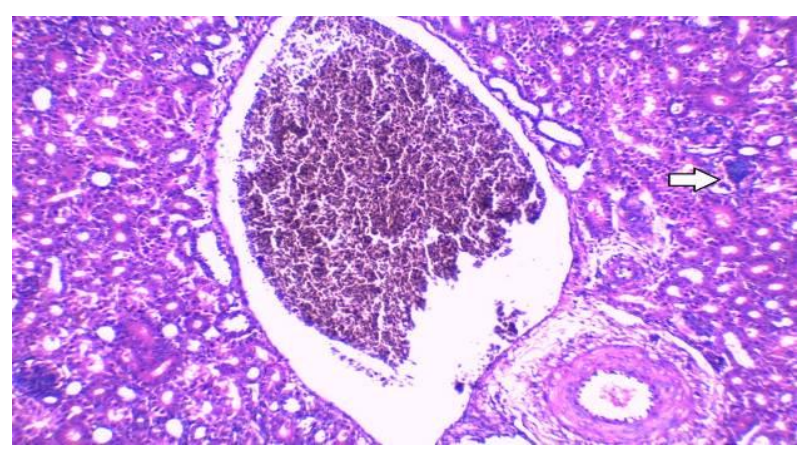

Fig. (16). kidney of aflatoxicated birds showing congested blood vessel and up normal glomeruli (arrow). $H$ and $E$. $\times 200$. 


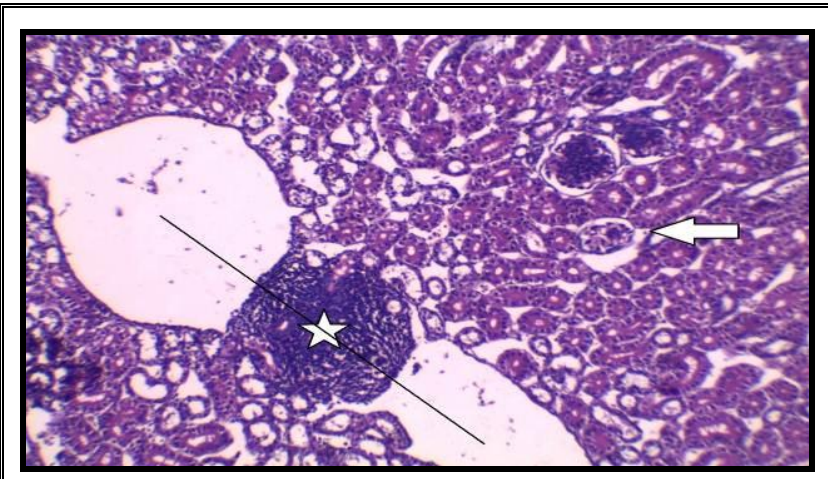

Fig. (17). kidney of aflatoxicated birds showing focus inflammatory reaction between two dilated vessels (asterisk), atrophy glomeruli (arrow). H and E. $\times 200$.

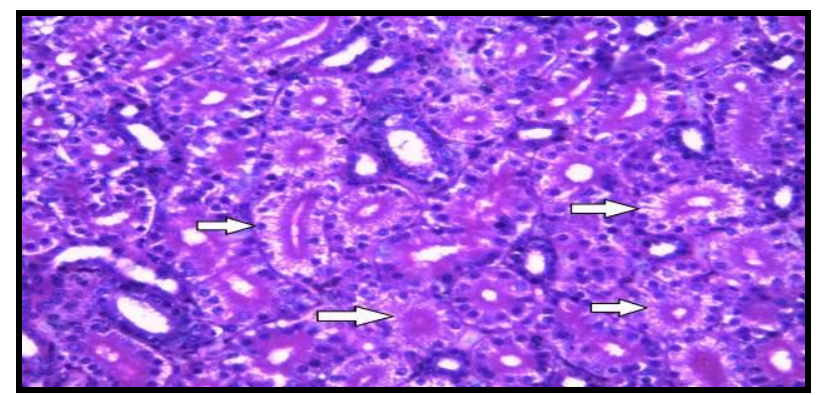

Fig. (19). High power magnification for the kidney of aflatoxicated birds showing hydropic degeneration of epithelial cells lining renal tubules (arrows). $\mathrm{H}$ and $\mathrm{E} . \times 400$.

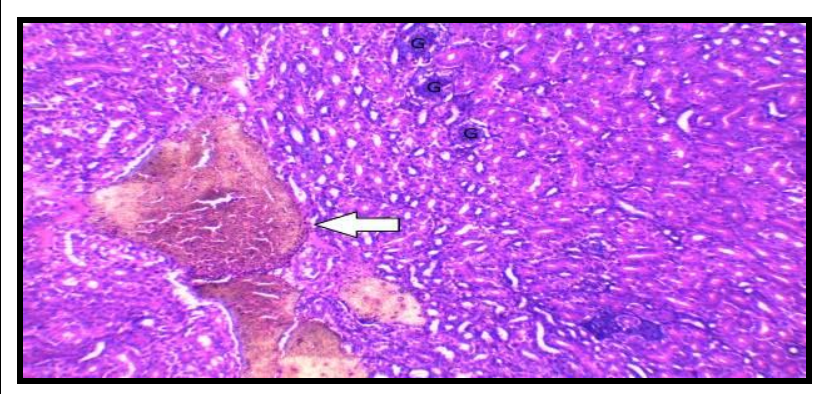

Fig. (21). kidney of aflatoxicated birds treated by $L$. acidophilus showing in normal glomeruli (G), congested blood vessel (arrow). $\mathrm{H}$ and $\mathrm{E} . \times \mathbf{2 0 0}$.

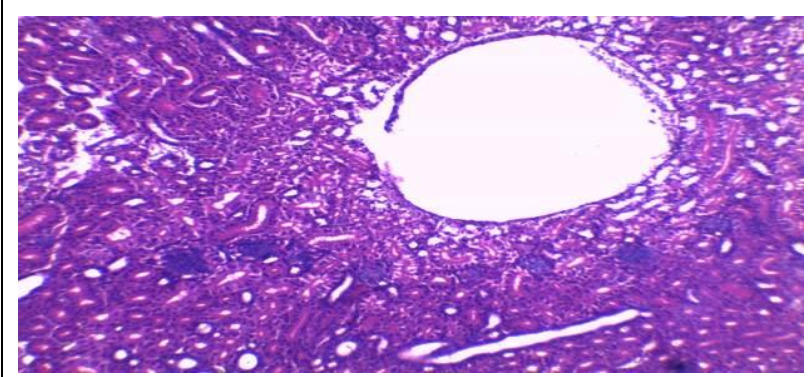

Fig. (23). Kidney of aflatoxicated birds treated by $s$. cerevisiae showing normal glomeruli, normal kidney tissues, but there was congested blood vessel. $\mathrm{H}$ and $\mathrm{E}$. $\times 200$.

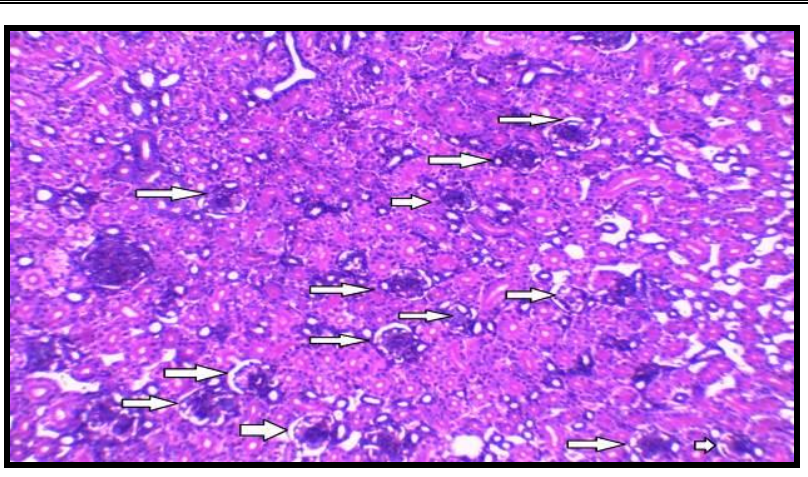

Fig. (18). kidney of aflatoxicated birds showing multi atrophy glomeruli (arrows). $\mathrm{H}$ and E. $\times 200$.

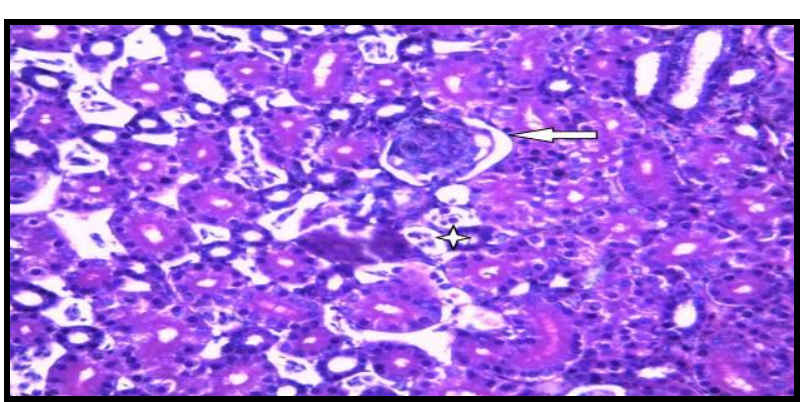

Fig. (20). High power magnification for the kidney of aflatoxicated birds showing thickened Bowman's capsule basement membrane of the glomerular capillaries (arrow), renal infiltration (asterisk). $\mathrm{H}$ and E. $\times \mathbf{4 0 0}$.

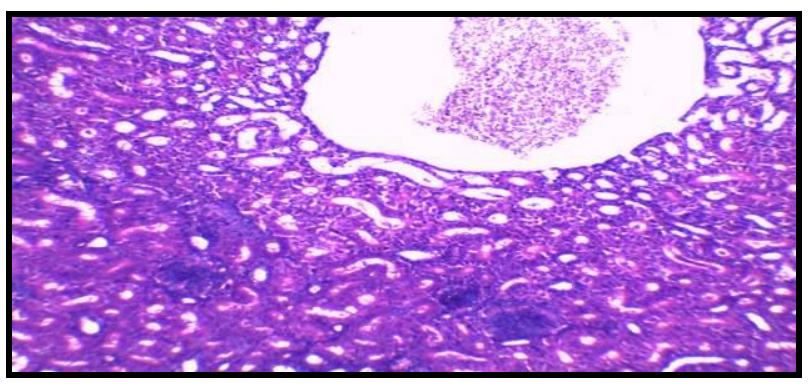

Fig. (22). kidney of aflatoxicated birds treated by $L$. acidophilus showing mild congested renal blood vessel. $\mathrm{H}$ and E. $\times 200$.

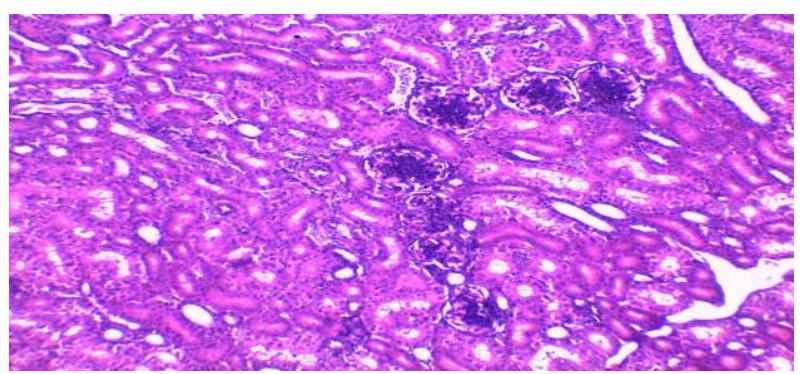

Fig. (24). Kidney of aflatoxicated birds treated by $s$. cerevisiae showing normal glomeruli, normal kidney tissues. $\mathbf{H}$ and $\mathbf{E} . \times 200$. 


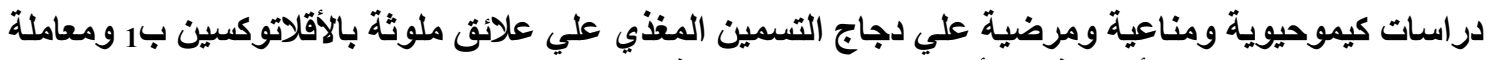
بيولوجيا باللاكتوباسيلس أسيدوفيلس أو السكاروميسس سيرفير النيسيا.

\author{
عادل السيد أبوزيد ، سعد زغلول الامراوي و طلعت خضر الريس
}

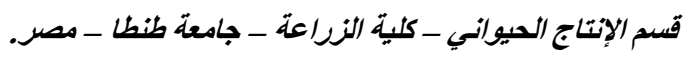

أجريت هذه الدراسة لإلقاء مزيد من الضوء علي الثأثيرات الوقائية لبكتريا اللاكتوباسيلس أسيدوفيلس أو خميرة السكاروميسس

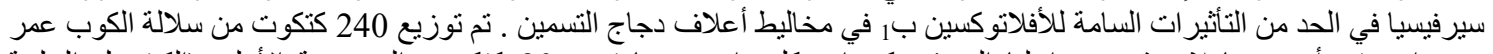

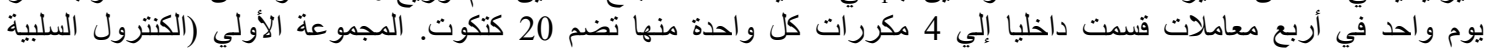

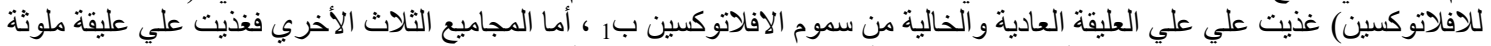

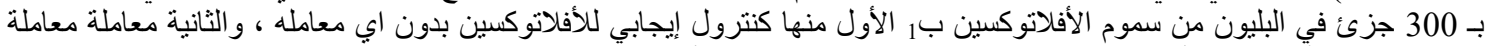

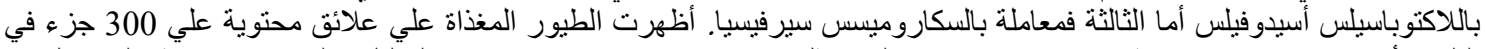

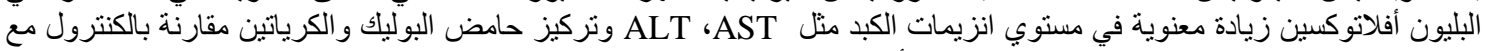

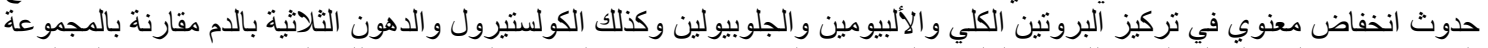

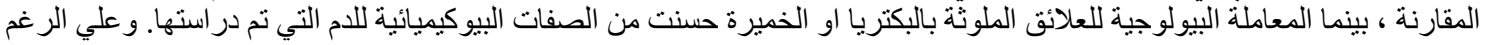

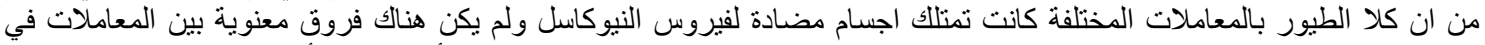

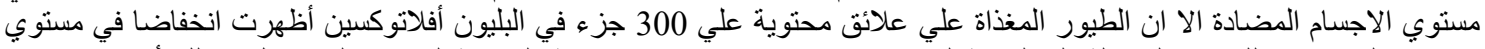

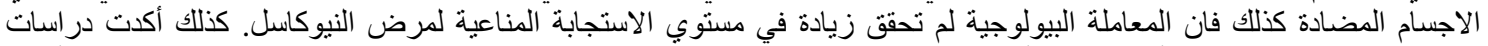

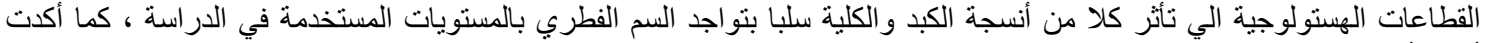

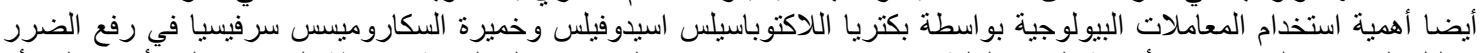

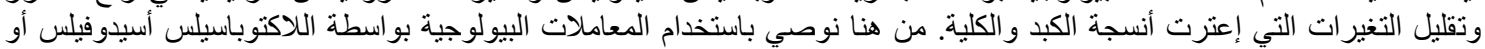
السكاروميس سيرفيسيا للتخفيف من الآثار السلبية لسموم الأفلاتوكسين بانئ في علائق دجاج التسمين. 